\title{
Humor in the Classroom: Implications for the Bibliographic Instruction Librarian
}

\section{Barbara MacAdam}

As the theoretical foundations of bibliographic instruction are examined increasingly in the context of learning theory and teaching methods, comparisons with the classroom environment found in academic settings are inevitable. The specific role of humor in the college classroom and its effect upon both learning and the communicative climate has been of interest to educational researchers, producing a concomitant body of literature. Characteristics peculiar to the bibliographic instruction classroom suggest that humor may have special benefits when employed by the librarian involved in user education. However, research studies indicate the need to take a second look at assumptions about the results of humor in the college classroom, particularly in the context of bibliographic instruction program objectives.

he role of user education programs in academic libraries of all sorts has become so soundly advocated and widely analyzed in recent years that bibliographic instruction as a concept hardly needs defending. Further, in actual practice, it would probably be difficult to find an academic library in the United States that was not presently engaged in some activity falling under the broad umbrella of user education. Literature, however, dealing specifically with teaching methods and learning theory as they relate to the librarian in the classroom has been less widely available until recently. The landmark work of Oberman and Strauch, Theories of Bibliographic Education, surveyed and analyzed, for the first time in depth, the theoretical foundations of bibliographic instruction in relation to conceptual frameworks of learning and teaching.

Still virtually unexamined in any detail are the personal characteristics of the teaching librarian as they come into play in the classroom, and how these characteristics influence learning. Humor as an acceptable tool in teaching carries the advantage of expressing the personality of the teacher as well as functioning as a method of communication. Further, certain elements peculiar to the bibliographic instruction classroom combine with an increasingly substantive body of research on humor in teaching to make an analysis of the role of humor in library instruction both interesting and timely.

\section{CLASSROOM INSTRUCTION IN THE ACADEMIC SETTING}

To accept the validity of the humorrelated educational literature applied to user education, one must understand the role of the teaching librarian and how it is both similar and dissimilar to the situation encountered by the nonlibrarian faculty. Beaubien, Hogan, and George describe the classroom lecture as the most common

Barbara MacAdam is coordinator, access and automated services, in the undergraduate library at the University of Michigan, Ann Arbor, Michigan 48109. 
form of bibliographic instruction with its foundations in academic tradition:

The single live lecture is by far the most prevalent form or mode of bibliographic instruction in an academic setting. No doubt this is due to the age-old prevalence of the lecture in education generally as the traditional method of group instruction. $^{2}$

They continue to emphasize that "ease in designing and delivering an effective single lecture is one of the most important skills needed for any public service library professional.,"3

The implication is clear that the teaching librarian shares the classroom experience with his/her nonlibrarian faculty counterpart and needs similar teaching skills. However, the emphasis on the single live presentation, christened the "one-shot," distinguishes in a fundamental way the difference between bibliographic instruction and the normal college course. In a one-hour presentation there is no period of adjustment for the librarian and student to form an ongoing relationship of mutual trust and rapport. Opportunity for followup on the material presented is limited or nonexistent, and the instructional objectives must be accomplished within a single, fifty-minute block of time. Paradoxically, however, the librarian who is likely to have only one opportunity at this single encounter with students probably has concrete goals for the class session in order to rate it a success. So in a sense the teaching librarian is under even greater pressure than the history professor to create in short order a communicative environment that will enhance learning while having a much more limited opportunity to do so.

Additional burdens may hamper the librarian teaching one-shot lectures. In the context of pressure to meet self-imposed standards requisite for a productive class session, the librarian may find tension created from continuously teaching "strangers" intensifies as the number of classes increases in the successful bibliographic instruction program. Further, if a bulk of classes are taught to similar groups of students (i.e., freshman English), the poten- tial is high for a sense of stressful tedium or burnout. These pitfalls for the teaching librarian argue all the more for teaching methods outside of sheer content that aid both the librarian and student in creating a positive and interesting learning environment. Of the many devices a teacher can employ to add interest, spontaneity, enjoyment, and warmth to the classroom, few are as widely palliative for both teacher and student as humor.

\section{OBJECTIVES OF \\ BIBLIOGRAPHIC INSTRUCTION IN THE ACADEMIC SETTING}

Working within the constructs described above, the bibliographic instruction librarian practices his/her craft with certain generally accepted goals:

- Providing students with an introduction to the basic principles of library research;

- Introducing students to the range and utility of the resources available in the academic library;

- Orienting students to the organization and physical plant of the library in terms of the principles of research;

- Inculcating a positive attitude on the part of students toward the library, the research process, and the librarian as professional.

With these objectives in mind, we can categorize them more generally as: (1) transmission of specific information, (2) increase in cognitive skills, and (3) attitude change or formation. Expressed in this fashion, humor can be analyzed in terms of its facilitating effect in accomplishing these objectives. Thus the questions the librarian who intentionally or spontaneously finds him/herself using humor in the college classroom will want to answer are:

1. Does humor have a positive or negative effect on the learning environment?

2. To what extent is humor employed in the college classroom?

3. Does humor enhance or impede retention of information?

4. What effect does humor have upon the listener's perception of the speaker? 


\section{POSITIVE LEARNING ENVIRONMENT AND THE BIBLIOGRAPHIC INSTRUCTION CLASSROOM}

Since Aristotle, thinkers and writers exploring the nature of communication have examined the elements that create an environment conducive to effective communication. Gilbert Highet, describing humor as one of the most important qualities of a good teacher, explains its relation to creating an atmosphere in which teacher and student work in unity toward the goals of thinking and learning:

When a class and its teacher all laugh together, they cease for a time to be separated by individuality, authority, and age. They become a unit, feeling pleasure and enjoying the shared experience. If that community can be prolonged or reestablished, and applied to the job of thinking, the teacher will have succeeded. ${ }^{4}$

Later researchers, hoping to establish empirically the factors determining an effective communicative climate, worked from the premise that communication is more efficient in classrooms in which the environment was perceived by students to be supportive rather than defensive. A supportive communicative climate is one in which students feel comfortable, feel safe in expressing their opinions, and do not feel their egos threatened. In such climates students feel more positive about both teacher and subject matter and retain significantly more information than in defensive settings. ${ }^{5,6}$ If we recall that the bibliographic instruction librarian is generally teaching a one-shot lecture, the need to create a positive classroom climate and a rapport with students becomes all the more obvious. Humor can be a natural icebreaker and stress reliever, breaking down the ingrained social barriers between teacher and student in the college classroom.

While the intuitive benefits of humor seem obvious, recent research studies indicate some surprising results of the effects of humor in the college classroom. Darling and Civikly ${ }^{7}$ discovered that teachers are perceived by students as being more straightforward and honest when they use no humor of any sort. Use of both tendentious (hostile) and nontendentious (nonhostile) humor increased students' perception that the climate was more defensive than supportive. Further, in sex-related findings, female teachers using tendentious humor and male teachers using nontendentious humor are both perceived as being more defensive than supportive by students. These findings are interesting in that they seem to contradict general perceptions of the effect of humor on the communicative climate. In addition, they point out that students judge men and women teachers differently. The researchers suggest that college instructors employing humor in the classroom contradict student expectations of just how a college teacher is "supposed" to act. Possibly since females are "expected" to act more nurturing and males aggressive and domineering, use of inverse concepts of humor conflict with these expectations. The authors indicate, "The results suggest that a teacher, whether male or female, using no humor is perceived as more neutral and detached than a teacher using either tendentious or nontendentious humor." ${ }^{18}$ They attribute this reaction to students' perception that deliberate humor is a sign of a teacher's intent to control the classroom and conclude, "Humor that is not perceived as being open, honest and spontaneous may be more destructive to the communicative climate than an absence of humor.",9

The practical implications of these results encourage librarians to question the standard assumption that any use of humor automatically enhances the communicative environment. Though the above research findings are only preliminary, they do suggest that the use of obviously planned jokes or attempts at levity may have precisely the opposite effect upon a classroom climate. Common sense alone should warn the bibliographic instruction librarian who teaches several times a week that stock bits of humor used over and over will seem stale and hardly spontaneous. Further, the sex-related findings suggest that student perception of tendentious or hostile humor is espe- 
cially negative when the instructor is a woman. The implications for a predominantly female profession cannot be ignored.

\section{PREVALENCE OF HUMOR IN THE COLLEGE CLASSROOM}

Study on the extent and nature of humor employed in the classroom is particularly interesting in light of the above findings. Bryant, Comisky, and Zillmann ${ }^{10}$ discovered that while 20 percent of the faculty at the University of Massachusetts reported no use of humor in their classes, 80 percent indicated the use of humor averaging 3.34 times per class. Further, 48 percent reported use of humor "tendentious" in category with tendentious defining humor that is hostile, sexual, or both in nature. Keeping in mind the sexrelated findings of Darling and Civikly, consider the following:

An astonishing disclosure for those who tend to stereotype females as timid and submissive is that female professors tended to utilize a substantially greater proportion of tendentious humor than their male colleagues ( 62 percent versus 43 percent). . . . Whereas males utilized a sexual theme in 12 percent of their readily classifiable humor, females used it 16 percent of the time. . . . female teachers have even more of an 'edge' in using nonsexual, hostile humor (45 percent versus 31 percent). ${ }^{11}$

Data related to "spontaneity" indicates, however, that most ( 65 percent) of the incidences of humor were perceived to be spontaneous. Moreover, in unexplained results, 83 percent of female humor was judged to be spontaneous by students as opposed to only 62 percent of the male humor. While the authors conclude, "at present there is no evidence for the effects of perceived spontaneity of humor either on perceptions of the teacher or on learning," the later research of Darling and Civikly supported the positive effects of spontaneity.

For bibliographic instruction librarians, two points of note emerge. First, the use of humor per se in the classroom will not put the librarian at odds with teaching practices of other academic instructors. Rather, a total absence of humor would distinguish the bibliographic instruction class. Second, spontaneous rather than belabored or artificial use of humor appears to be a significant element in creating a positive communicative climate.

\section{HOW CLASSROOM HUMOR AFFECTS STUDENTS' PERCEPTION OF COLLEGE TEACHERS}

As mentioned previously, bibliographic instruction librarians expend an exceptional amount of energy, commitment, and ego each time they enter the classroom. They are concerned not only with the student absorption of the information presented, but probably also with the impression they are making on the student or faculty member. As Beaubien, George, and Hogan indicate:

The public relations value of the one-shot lecture cannot be overstated, both in terms of the visibility of the professional librarian within the user community and in terms of the library's willingness as an institution to cater to the specific needs of its clientele. The library should be able to provide on demand, cogent, interesting, perhaps even entertaining lectures that highlight the library's resources and the processes to exploit it. ${ }^{12}$

This position suggests that both the library's image and that of the librarian are at stake in a certain sense when the librarian enters the classroom, the more natural turf of the nonlibrarian faculty. This pressure, coupled with the librarian's instinctive need to be recognized as a professional and the fairly general student attitude that neither libraries not librarians are especially interesting, presents a special conundrum. The fine line between creating interest and appearing suitably "academic" may encourage the librarian to use humor, all the while fearing it might look unprofessional.

A significant body of research provides some reasonable indication of how humor affects college students' perceptions of classroom teachers. The research can be divided into two areas:

1. How humor affects perception of the teacher as a person (warmth, intelligence, etc.); 
2. How humor affects perception of the credibility of the teacher, or the reliability of the information being presented (ethos).

\section{Teacher Perception}

Bryant and others ${ }^{13}$ found that when students were asked to evaluate college teachers on the basis of their appeal, method of delivery, competence, and overall teacher effectiveness, male and female professors were judged differently when they used humor. For male teachers, use of humor was related to higher positive evaluations than those using no humor, regardless of the particular type of humor employed (hostile, nonhostile, sexual, nonsense, etc.). Female teachers who used humor, however, generally received lower evaluation scores on competence and delivery as well as on the measure of overall teaching effectiveness. Most interesting of all, positive correlations for females were limited to the appeal factor alone and, surprisingly, were associated only with the frequent use of hostile and sexual-hostile humor; females employing any other type of humor (such as nonsense or self-disparagement) suffered a loss of appeal. The researchers hypothesize

Another, and perhaps more convincing explanation of the apparent sex differences in humor use is sex stereotyping by students. Students may expect, accept, and even appreciate an occasional joke coming from a male professor. The joking female professor, in contrast, may be perceived as a person breaking an unspoken rule of 'appropriate' classroom conduct. Loss of appeal and related aspects of teacher evaluation may result, in turn, from this perception of unfitting behavior (or "misconduct") ${ }^{14}$

Commenting on the seemingly contradictory findings that female teacher appeal was actually enhanced by use of aggressive and hostile humor, the authors suggest, "It may be that the use of hostile humor by female professors exhibits a degree of aggressiveness that grants them assertiveness and 'authority' and makes them the equal of their male colleagues." ${ }^{\prime 15} \mathrm{Fe}-$ male teachers employing hostile humor seem to be allowed such conduct because they are perceived as more authoritarian or "malelike" and hence are permitted corresponding classroom behavior.

Attempting to correlate college students' perceptions of teachers with sex of student, sex of teacher, and type of humor employed, Tamborini and Zillman ${ }^{16}$ established four categories of teaching style: no use of humor, use of sexual humor, use of other-disparaging humor, and use of selfdisparaging humor. Male and female students were asked to rate teachers on measures of appeal and intelligence. Lecturers employing self-disparaging humor were given higher ratings of appeal when lecturer and students were of the same sex. Inversely, teachers using sexual humor were found to be less appealing to members of the same sex but more appealing to students of the opposite sex.

Accordingly, male professors using sexual humor may find that any increase in their appeal to female students comes at the expense of appeal to male students; and for female professors using sexual humor, any increase in their appeal to male students will likely be offset by a decrease in their appeal to female students. ${ }^{17}$

Variations in humor, or complete absence of humor, however, had no measureable effect on the perception of the lecturer's intelligence.

\section{Teacher Credibility (Ethos)}

The willingness of the listener to accept the message of the speaker based in large part on the perceived character of the speaker (ethos) has been studied in limited fashion related specifically to humor. Kennedy was able to conclude, "The ethos of the source who employed humorous content in a persuasive message will be regarded more favorably four weeks later than the ethos of the source who presented the serious persuasive message." 18

For short-term reactions, lecturers employing humor were perceived higher in ethos scale only in regard to the dynamism factor (dynamism implying the speaker as aggressive, emphatic, bold, active, or energetic rather than meek, hesitant, timid, passive, or tired). Humor had no effect on evaluations of ethos of a speaker in terms of safety (safe, just, kind, friendly, honest) or qualification (trained, 
experienced, skilled, qualified, informed).

\section{EFFECT OF HUMOR ON LEARNING}

Beaubien, Hogan, and George indicate, "Humorous or offbeat examples can highlight student interest and-in theoryretention. ${ }^{\prime 19}$ Kaplan and Pascoe confirm that, while immediate comprehension was not facilitated by the use of humorous examples, "Upon retesting, however, retention of concept humor materials was significantly improved by viewing a lecture with humorous examples illustrating concepts. ${ }^{\prime 20}$ Their research further indicated that the material retained was that specifically illustrated by humorous examples; there was no increased comprehension or retention for material unrelated to the humorous examples. Kennedy also found that the use of humorous content in the persuasive message did not increase the overall recall of information contained in the message. ${ }^{21}$

\section{SUMMARY AND CONCLUSIONS}

In light of research that is contradictory or inconclusive in supporting humor as a facilitating tool in college classroom teaching, what role should the bibliographic instruction librarian assign humor in his/her teaching tools? If the librarian is female, she may well want to consider that the type of humor she employs may make her appear less effective and competent than her male counterpart, and that student expectations may allow her considerably less latitude than male librarians in the classroom. She may further face the quandary of trying to enhance appeal through use of aggressive hostile humor, which many teachers of both sexes may find uncomfortable or inappropriate for the library instruction setting. On the plus side, any librarian using humor can be assured that most other college teachers do so in fairly liberal doses. Use of humor will not make a librarian appear less intelligent or less "academic." In addition, there is some evidence that the character perception or ethos of the teacher may actually be enhanced by use of humor in a presentation.

Since any librarian involved in user education must be concerned about student absorption or retention of information, knowing that use of specific humorous examples may actually increase retention for that particular material is a reassuring reinforcement of the beneficial effects of humor. Library instruction, in fact, lends itself ideally to creative examples. However, the use of forced or obviously staged bits of humor may actually have a negative effect on the communicative and learning environment. Beaubien, Hogan, and George warn that "serious students and faculty members who attend your lectures are likely to be turned off entirely by what they perceive as a sideshow act without substance.",22

Ultimately, however, the art of the practitioner replaces the intellectual vision of the theoretician in the classroom. While empirical results can help the librarian validate or question assumptions, there comes a time when teacher faces students and common sense, instinct, experience, personal style, and professional conviction must temper research findings. Bibliographic instruction librarians willing to examine their teaching methods seriously and to develop a foundation in learning theory can comfortably use humor in the classroom if it suits them and probably find that the overall results will conform to the objectives of their user education program.

\section{REFERENCES}

1. Cerise Oberman and Katina Strauch, Theories of Bibliographic Education (New York: Bowker, 1982).

2. Anne K. Beaubien, Sharon A. Hogan, and Mary W. George, Learning the Library (New York: Bowker, 1982), p.155.

3. Ibid.

4. Gilbert Highet, The Art of Teaching (New York: Vantage Books, 1956), p.56. 
5. J. R. Gibb, "Defensive Communication," Journal of Communication 11:141-48 (Sept. 1961).

6. E. R. Hays, "Ego-threatening Classroom Communication; A Factor Analysis of Student Perceptions," Speech Teacher 19:43-48 (Jan. 1970).

7. Ann Darling and Jean M. Civikly. "The Effect of Teacher Humor on Classroom Climate," in Proceedings of the Tenth International Conference on Improving University Teaching, 1984 (University of Maryland), p.798-806.

8. Ibid., p.804.

9. Ibid.

10. Jennings Bryant, Paul Comisky, and Dolf Zillman, "Teachers' Humor in the College Classroom," Communication Education 28:110-18 (May 1979).

11. Ibid., p.116.

12. Beaubien, Hogan, and George, Learning the Library, p.158.

13. Jennings Bryant and others, "Relationship Between College Teachers' Use of Humor in the Classroom and Students' Evaluations of their Teachers," Journal of Educational Psychology 72:511-19 (Aug. 1980).

14. Ibid., p.518.

15. Ibid.

16. Ron Tamborini and Dolf Zillman, "College Students' Perception of Lecturers Using Humor," Perceptual and Motor Skills 52:427-32 (Apr. 1981).

17. Ibid., p. 431 .

18. Allan J. Kennedy, "An Experimental Study of the Effect of Humorous Message Content Upon Ethos and Persuasiveness," (Ph.D. diss., Univ. of Michigan, Ann Arbor, 1972), p.138.

19. Beaubien, Hogan, and George, Learning the Library, p.190.

20. Robert M. Kaplan and Gregory C. Pascoe, "Humorous Lectures and Humorous Examples: Some Effects Upon Comprehension and Retention," Journal of Educational Psychology 69:61-65 (Aug. 1977).

21. Kennedy, "An Experimental Study," p.123.

22. Beaubien, Hogan, and George, Learning the Library, p.191. 